\title{
ПРОЕКТ НОВОГО ПОРЯДКУ КОНКУРСНОГО ВІДБОРУ ПІДРУЧНИКІВ
}

\author{
Доповідь на слуханнях у Комітеті Верховної Ради України з питань освіти, \\ науки та інновачій на тему: "Якість підручників та навчальних посібників \\ для Нової української школи» 26 травня 2021 р.
}

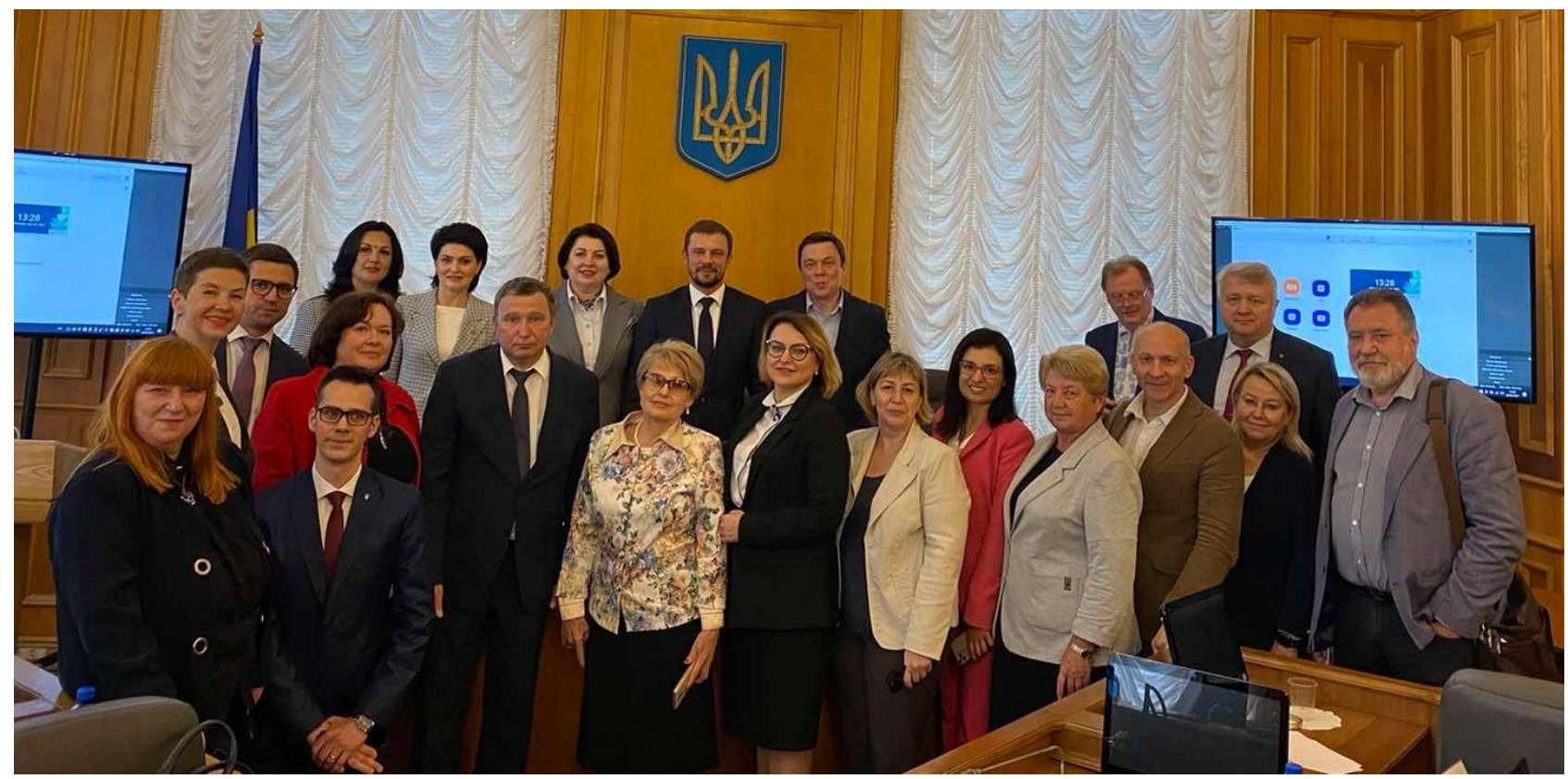

ТОПУЗОВ Олег Михайлович доктор педагогічних наук, профресор, дійсний член (академік) НАПН України, віце-президент Національної академії педагогічних наук України, директор Інституту педагогіки Національної академії педагогічних наук України, м. Київ, Україна (iD) $\curvearrowright$
Анотація. У доповіді наголошено на важливості забезпечення якості української навчальної книги, що засвідчує успішну реалізацію освітнього процесу і спрямовано на істотне вдосконалення системи створення шкільних підручників та посилення відповідальності перед суспільством та вітчизняною школою. Висвітлено стан забезпечення підручниками та навчальними посібниками здобувачів загальної середньої освіти $і$ педагогічних працівників в Україні та схарактеризовано його особливості. Представлено науковий доробок вчених авторських колективів Інституту педагогіки НАПН України щодо створення понад 160 підручників та посібників упродовж 2018-2021 рр. Наведено вимоги до якісного сучасного підручника, що обгрунтовано за результатами проведеного науковиями Інституту педагогіки НАПН України опитування здобувачів загальної середньої освіти. Особливу увагу звернуто на пропозиції вчених НАПН України з метою забезпечення належної якості навчальної літератури, зокрема для Нової української школи.

Ключові слова: якість навчальної книги; експертиза підручників; підручникотворення; навчальне книговидання; Інститут педагогіки НАПН України.

Забезпечення якості вітчизняної навчальної літератури є одним із пріоритетних напрямів успішної реалізації освітнього процесу і спрямовано на істотне вдосконалення системи створення шкільних підручників та посилення відповідальності, зокрема щодо викликів, які постали перед суспільством та українською школою упродовж останніх років. 


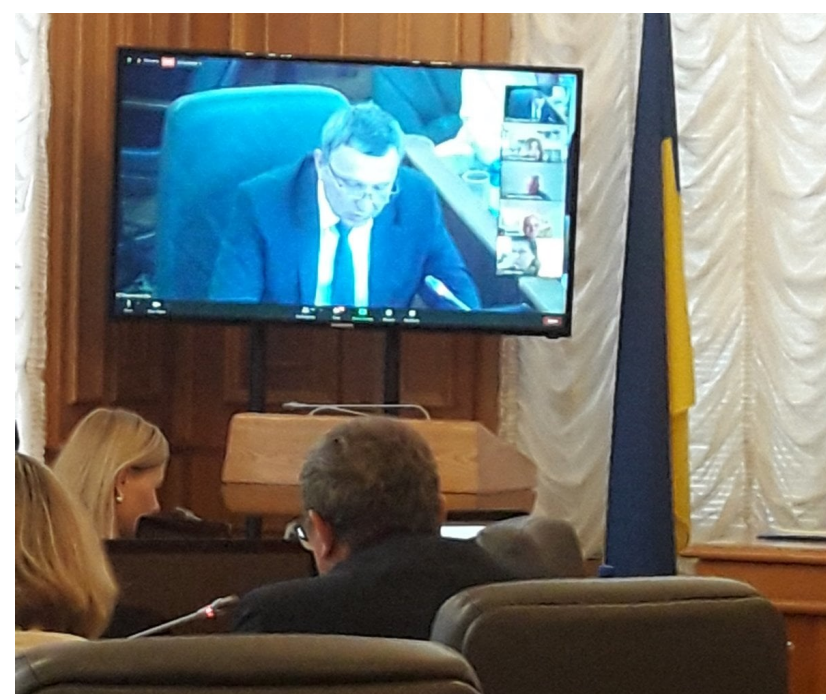

І. В Україні загалом сформовано індустрію навчальної книги

У її основу закладено ідеї багатоваріантності підручника, конкурсного відбору поданих рукописів, надання педагогам права вибору майбутнього підручника з метою визначення його накладу і фінансування видання. Попри наявні поки що недоліки в їх реалізації, вони створюють передумови для досягнення належної якості української навчальної книги.

Незважаючи на значну роботу, здійснену 3 формування індустрії навчальної книги в країні, все ж непоодинокими є випадки потрапляння до закладів загальної середньої освіти підручників низької якості. Причинами цього $€$ недосконалість чинних механізмів підготовки навчальної книги, зокрема експертизи майбутнього підручника, починаючи від критеріїв його оцінювання, недостатньої кваліфікації експертів, самої організації експертизи до попередньої апробації підручника у навчальному процесі, яка нині відсутня.

Зарадити ситуації може істотне оновлення процедури підготовки підручників, зокрема запровадження ринкових механізмів у формуванні держзамовлення, удосконалення системи критеріїв експертного оцінювання рукопису майбутнього підручника з чітким визначенням відповідних показників, які можна однозначно виміряти. Також необхідною $€$ сертифікована підготовка кваліфікованих експертів навчальної книги та обов'язкове передбачення етапу попередньої апробації в навчальному процесі як необхідного складника експертизи майбутнього підручника.

В Україні процедура розробки та контролю за якістю шкільних підручників регламентується відповідними порядками і положеннями, які періодично зазнавали змін і модифікацій.

Ключовими документами цього періоду можна назвати «Порядок надання навчальній літературі, засобам навчання і навчальному обладнанню грифів та свідоцтв Міністерства освіти і науки України», який діяв із 2008 р. до 2020 р., та «Положення про конкурсний відбір підручників», які практично щороку змінювалися, коли оголошувався конкурс для відповідної паралелі класів.

Серед ключових новацій, які тією чи іншою мірою застосовувалися для поліпшення умов конкурсного відбору, можна назвати такі.

Навчання експертів навчальної літератури, ініційоване НАПН України, яке, на жаль, не мало фінансової підтримки, тож здійснювалося на волонтерських засадах і не відіграло повноцінно своєї ролі. Проте ця ідея трансформувалася в інструктивно-методичні рекомендації для експертів, і так чи інакше присутня й у теперішніх конкурсних умовах відбору підручників. Проте оплата праці експертів як була, так і лишається неурегульованим питанням.

Вибір підручників закладами освіти. Із 2014 р. й до цього часу існує процедура вибору підручників учителями закладів освіти, яка також за ці роки набула ознак адміністративного впливу. Незважаючи на те, що має бути вільний вибір і навіть існує «гаряча лінія», на яку можна зателефонувати у разі виявлення порушень, на практиці прослідковується вплив адмінресурсу та видавництв у «просуванні» своїх підручників.

Антидискримінаційна експертиза. Введена $з$ 2015 р., така експертиза мала свої «плюси» i «мінуси». До переваг належить те, що дійсно автори підручників, експерти, видавці змінили стереотипні підходи до текстів завдань, малюнків, звернень до учнів тощо. Недоліки - це деякі недолугі рекомендації, які надають експерти цієї експертизи (наприклад, вислів «Українська мова солов'їна» вважався дискримінаційним щодо інших мов; нарікання, що в підручниках фізики портрети лише вчених-чоловіків тощо).

В умовах оновлення законодавства про освіту відбуваються відповідні зміни й у процедурах підручникотворення. Затверджено новий Порядок надання грифів навчальній літературі, який має сприяти підвищенню якості підручника.

Упродовж перших чотирьох років функціонування Нової української школи авторські колективи Інституту педагогіки НАПН України підготували 
83 найменування підручників та 85 найменувань посібників для початкової школи.

\begin{tabular}{|c|c|c|}
\hline Роки & Підручники & Посібники \\
\hline 2018 & 30 & 35 \\
\hline 2019 & 14 & 20 \\
\hline 2020 & 20 & 20 \\
\hline 2021 & 19 & 10 \\
\hline Усього & 83 & 85 \\
\hline
\end{tabular}

Чотири роки поспіль науковці НАПН України здійснюють дидактико-методичний супровід навчання у початковій школі в умовах реформи. 3 метою реалізації Державного стандарту початкової освіти та типових освітніх програм для 1-2 і 34 класів закладів загальної середньої освіти, розроблених у НАПН України під керівництвом О.Я. Савченко, вчені академії стали авторами та співавторами підручників 3:

- української мови (О.Я. Савченко, К.І. Пономарьова, М.С. Вашуленко, О.В. Вашуленко), у тому числі для закладів із викладанням мовами національних меншин

Білоскаленко, О.М. Петрук);

(Н.І. Богданець-

- математики (О.В. Онопрієнко, С.О. Скворцова, Н.П. Листопад);

- курсу «Я досліджую світ» (Н.М. Бібік, І.В. Андрусенко);

- інформатики (Н.В Морзе);

- іноземної мови (В.Г. Редько);

- мистецтва (Л.М. Масол), які перемогли у всеукраїнських конкурсах проєктів підручників у 2018, 2019, 2020, 2021 роках і видаються за державні кошти. Підручники четвертий рік поспіль лідирують за кількістю вибору вчителями країни. Так, за підручниками науковців НАПН України в третьому класі навчаються української мови та читання понад 260 тис. учнів, математики - понад 290 тис., курсу «Я досліджую світ» понад 110 тис. учнів.

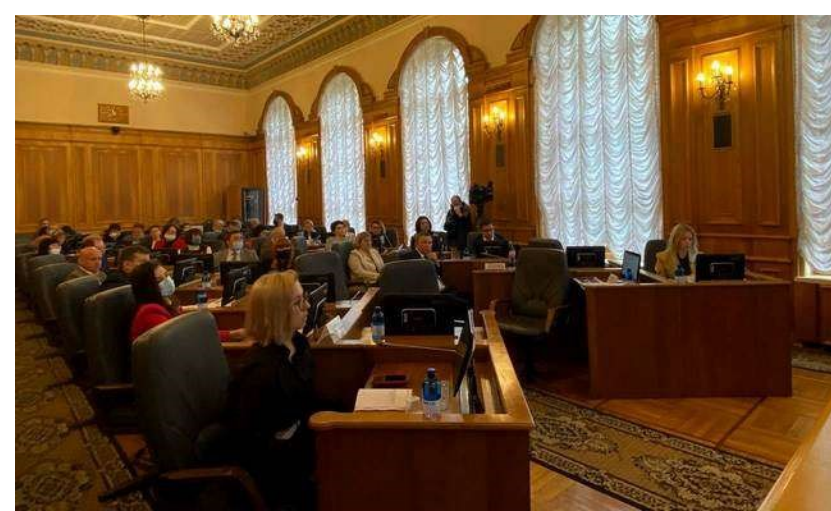

Із затвердженням Державного стандарту початкової освіти (2018р.) і нових типових освітніх програм особливо актуальною стала необхідність створення сучасного шкільного підручника, де буде розгорнуто оновлений зміст навчання молодших школярів на засадах компетентнісного підходу. Основною новацією у цьому контексті вважаємо орієнтацію навчальної книги на досягнення учнями очікуваних і обов'язкових результатів навчання. Нові цілі початкової освіти й зумовлені ними результати навчання спричинили зміни методичних підходів до реалізації функцій підручників, а саме: встановлено курс на зменшення питомої ваги готової інформації на користь засвоєння учнями компетентнісно орієнтованого навчального матеріалу, набуття особистого досвіду творчої діяльності.

У побудові концепцій підручників автори вчені НАПН України - використали наукові напрацювання у галузі підручникотворення, дидактики початкової школи, методик навчання предметів та інтегрованих курсів. Змістове наповнення підручників і їх методичний апарат розроблено з урахуванням нормативних вимог до змісту й результатів навчання молодших школярів, науково обґрунтованих поглядів на побудову освітнього процесу.

Науковці НАПН України (автори підручників) забезпечили дидактичний і методичний ресурс для досягнення учнями очікуваних і обов'язкових результатів навчання, визначених нормативами для Нової української школи.

II. Сучасний стан забезпечення підручниками та навчальними посібниками здобувачів загальної середньої освіти і педагогічних працівників в Україні позначений такими особливостями:

1. Централізація навчального книговидання на рівні МОН України, вкрай недостатне фінансування видання навчальної літератури. Міністерство фактично диктує умови відбору та виготовлення накладів, визначає кількість підручників для учнів та вчителів, не завжди враховуючи вибір закладів освіти. Середня вартість одного примірника нижча від середньоєвропейської у 810 разів і становить трохи більше 40 гривень за примірник. Проте навіть за таких умов закуплених підручників не вистачає для повного регулярного оновлення навчальної літератури. Через це у навчальному процесі одного класу часто використовуються підручники різних років видання, які створені відповідно до різних навчальних програм та правописних норм української мови. 
Недостатньо обґрунтований нормативно встановлений п'ятирічний термін експлуатації підручників призводить до ускладнення або неможливості використання їх учнями протягом заключних років користування, негативно позначається на якості освітнього процесу, несе ризики для здоров'я учнів.

2. Брак часу на створення нового покоління підручників. На створення нових підручників авторам виділяється два-три місяці часу, конкурсні процедури експертизи та відбору навчальних матеріалів відбуваються у щільному графіку підготовки до нового навчального року, що унеможливлює якісну роботу над проєктами підручників та досконалу експертизу.

3. Неерективна система експертизи проєктів підручників. Перед виданням проєкти підручників проходять експертизу коштом учасників конкурсу. Результати експертизи $є$ підставою для схвалення чи відхилення підручника від використання у навчальному процесі. Експертиза майже не впливає на підвищення якості підручників. Процедура експертизи є закритою для громадського контролю. Як підтверджують численні результати розглядів апеляційних скарг учасників конкурсу, експерти часто зловживають правом відхиляти проєкти підручників від участі у конкурсі, посилаючись на власні, переважно суб'єктивні міркування. Учителі позбавлені можливості уповні реалізовувати своє право на академічну самостійність і вільно вибирати навчальні матеріали з усіх запропонованих варіантів. Подекуди їх вибір нічим не завершується, оскільки підручник не набирає необхідного накладу.

4. Формати підручників недостатні для повноцінної реалізації змісту та технологій навчання. Обсяг підручника обмежений гігієнічними нормами і коштами, що виділяє $\mathrm{MOH}$ України на його друк. Підручник залишається несамодостатнім навчальним виданням, що призводить до витрат коштів батьками на купівлю додаткової літератури. Водночас більшу популярність серед учнів і вчителів мають видання так званого європейського формату, виготовлені за іншими гігієнічними нормами, коли в одній навчальній книзі поєднуються атрибути підручника й робочого зошита або створюється навчальнометодичний комплект.

5. Вимога конкурсного відбору щодо відповідності підручника змісту навчальної програми обмежує авторів у виборі альтернативних підходів до викладу навчального матеріалу.

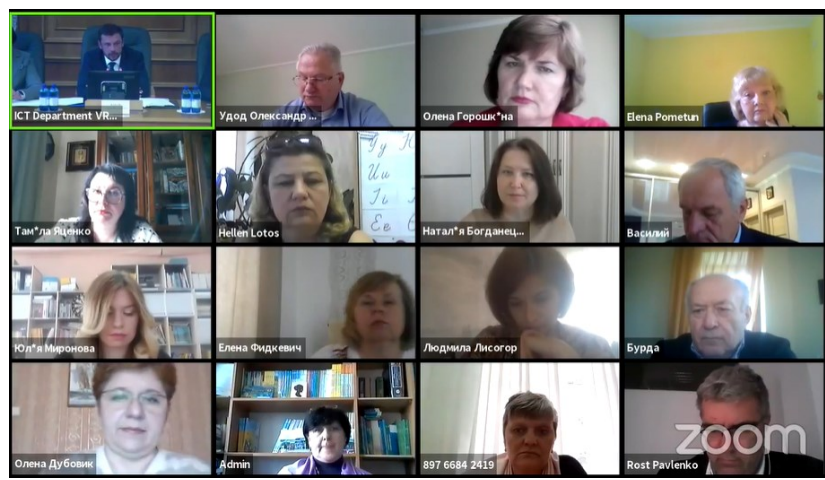

Нерідко підручники відрізняються лише назвою видавництв і порядком слів, а не варіативністю методичних підходів чи оригінальністю структури змісту. Вимогу конкурсу щодо узгодження 3 модельними програмами потрібно замінити на узгодження з вимогами стандарту.

III. Якісний підручник очима учнів і вчителів

Науковці Інституту педагогіки НАПН України провели дослідження з оцінювання здобувачами загальної середньої освіти інформативності чинних підручників з фізики, хімії, біології та географії для 9 класу за факторами «важливий» (вдалий, інноваційний, захопливий, багатоплановий), «природний» (близький, конкретний) та «простий». Було встановлено інформативність цих факторів для різних підручників. Зокрема:

- біології: важливість - 18,9\%, простота 18,8 \%, природність - 21,1\%;

- географії: важливість - 27,9\%, простота 26,5\%, природність - 16,7\%;

- фізики: важливість - 25,1\%, простота 19,5 \%, природність - 14,9\%;

- хімії: важливість - 24,1\%, простота $17,8 \%$, природність - 36,6 \%.

За результатами дослідження встановлено, що шкільний підручник у свідомості учня $\epsilon$ фрагментом того середовища навчання, у якому здійснюється його навчальна діяльність. Саме в процесі активного використання підручника як інструмента пізнання, знаряддя діяльності в учня формується власне ставлення до цього об'єкта реальної дійсності. 3 огляду на це, формується і відповідна система показників, яка виражається в оцінці учнем знаряддя діяльності, що його він використовує у процесі освоєння того чи іншого навчального предмета. Порівняння розташування характеристик об'єктів оцінювання у факторних просторах свідчить про відмінність образів, сформованих в учнів щодо характеристик різних підручників, використовуваних у процесі навчальної діяльності в системі «учень - підручник». 
Отже, розробляючи сучасні підручники, потрібно враховувати, що основними їх споживачами є здобувачі освіти, для яких інформативність навчальної книжки визначається не лише відповідністю ії змісту навчальній програмі. Окрім того, доцільно враховувати й відмінність сприйняття учнями підручників із різних предметів, тоді як вимоги до них є традиційно уніфікованими.

За результатами широкого дослідження можливостей чинних підручників щодо формування в учнів 1-9 класів ключових компетентностей у контексті цілей PISA, проведеного науковцями Інституту педагогіки НАПН України в 2021 р. (охоплено понад 3 тис. педагогічних працівників), було виявлено таке.

Лише 25 \% вчителів аналізують зміст підручників щодо його потенціалу в формуванні ключових компетентностей (852 респондентів 3 3331, рис. 1).

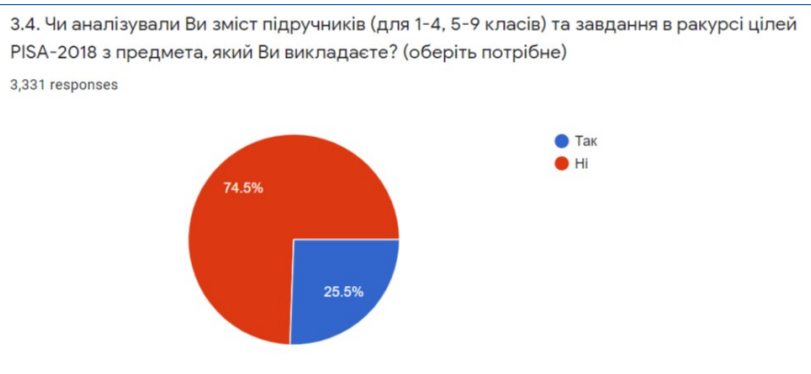

Рис. 1. Зміст підручників в контексті цілей PISA

На думку більшості вчителів (близько 80 \%), кількість завдань у підручниках, спрямованих на формування ключових компетентностей, не перевищує 50 \% (рис. 2).

3.6. Якщо Ви здійснювали аналіз підручників, то вкажіть який відсоток завдань спрямований на формування ключових компететностей і базових навичок і на досягнення цілей PISA? (оберіть потрібне) 1,379 responses
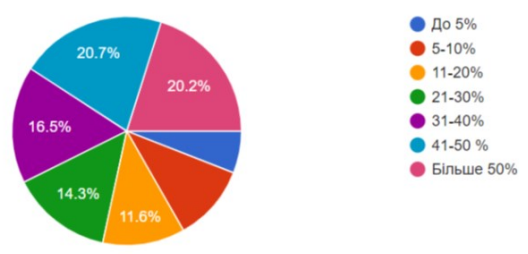

Рис. 2. Відсоток завдань, спрямованих на формування ключових компетентностей

Близько 70 \% педагогічних працівників вважають, що підручники не забезпечують досягнення цілей PISA (рис. 3).

Таким чином, актуальною є проблема посилення компетентнісної спрямованості змісту та методичного апарату сучасних підручників.

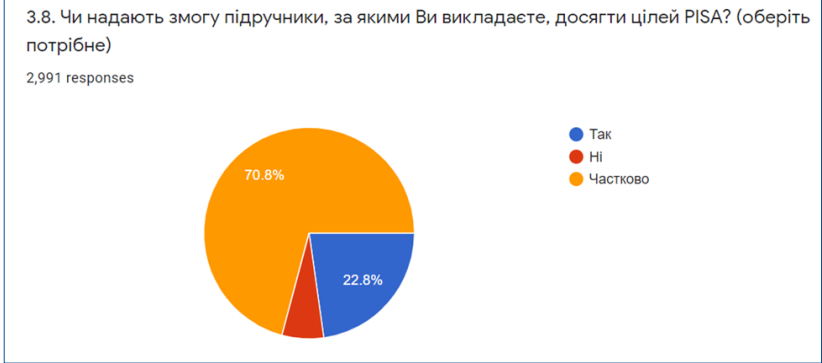

Рис. 3. Підручники у забезпеченні досягнення цілей PISA

\section{IV. Пропозиції}

3 огляду на зазначене та з метою забезпечення належної якості навчальної літератури для Нової української школи пропонуємо:

Кабінету Міністрів України, Міністерству освіти і науки України, Міністерству економіки, Міністерству фінансів:

- розробити й апробувати нові ринкові механізми у формуванні держзамовлення.

Кабінету Міністрів України, Міністерству освіти і науки України внести зміни та доповнення до чинних нормативно-правових актів з метою:

- регулярного щорічного визначення переліку назв підручників та обсягів їх накладів, що будуть видані за бюджетні кошти, виходячи з потреби стовідсоткового забезпечення підручниками усіх здобувачів повної загальної середньої освіти й педагогічних працівників. Переглянути доцільність видання підручників із деяких предметів («Мистецтво», «Технології» (трудового навчання), «Інформатики», «Здоров'я, добробуту, безпеки», «Етики», які можуть бути замінені на робочі зошити або іншу навчальну літературу;

- дотримання єдиних правил щодо видання та перевидання підручників, що були у використанні в навчальному процесі, виходячи з результатів вибору проєктів підручників закладами освіти;

- фінансових стимулів для розроблення нового покоління навчальних матеріалів, поступового переходу встановлення фінансування видання підручників на вищому рівні бюджетних видатків. Доцільно практикувати можливість придбання підручників на комерційних засадах. Слід підвищити авторську винагороду авторам підручників у 2-4 рази та запровадити більш оптимальний рівень рентабельності виробництва навчальної літератури;

- оголошення переліку назв підручників і посібників, проєкти яких будуть брати участь у відборі, не пізніше ніж за шість-вісім місяців до початку процедур відбору. Це забезпечить достатній часовий проміжок для підготовки 
якісного змісту майбутнього підручника. Усі процедури підготовки проєктів, відбору підручників та виготовлення накладів мають відбуватися у розумні та достатні терміни;

- забезпечення ефективної системи підготовки експертів та проведення фахової експертизи навчальної літератури, яка має носити не дозвільний, а допоміжний характер, маючи на меті виключно покращення проєктів підручників. Критерії експертизи мають бути заздалегідь визначені нормативно-правовими актами;

- повернення процедури апробації підручників, але не під час, а до масового впровадження;

- встановлення раціональних та прозорих процедур конкурсного відбору підручників, що друкуються за державні кошти. Громадськість повинна мати можливість контролювати конкурсні процедури, учасники конкурсу повинні мати право на оскарження порушень з боку суб'єктів владних повноважень під час конкурсу зокрема, повноцінної реалізації ідеї вільного вибору підручника, яка не працює ефективно щодо формування реальних накладів підручників учителями, і потребує належних управлінських рішень.

Міністерству освіти і науки України, Інстиmуту модернізації змісту освіти спільно 3 Національною академією педагогічних наук України, асоціацією книговидавців, представниками видавництв:

- удосконалити експертне оцінювання підручників, яке має спрямовуватись передусім на науковий рівень змісту підручників та структуру текстів, а не на фіксації наявності різноманітних елементів і рубрик. Нагромадження різножанрової інформації в кожному окремому параграфі (факти, історія, персоналії, цікавинки тощо) утруднює роботу 3 текстом, виокремлення основного і другорядного. Зі сторінок підручників практично зник наратив (оповідь), який виконує функцію пояснення і може зацікавити читача. Переважають кліпові повідомлення, що розсіюють увагу учня;

- здійснювати навчання не лише експертів, а й потенційних авторів підручників, редакторських колективів.

3 цією метою варто приділити увагу таким особливостям підручникотворення.

Навчальний матеріал підручника має враховувати особливості навчальної діяльності сучасних учнів (вони народилися, коли інтернет повністю увійшов до повсякденного життя):
- краще засвоюють укрупнений, структурований навчальний матеріал, а не громіздкі тексти підручників, краще сприймають візуальну інформацію;

- орієнтуються на практичне використання знань;

- зосереджені на конкретних, не занадто віддалених навчальних цілях;

- комунікують у віртуальних «групах», тому потребують зворотного зв'язку, роботи у групах, обміну досвідом тощо.

Зміст підручника має бути сочіально ефективним і практично спрямованим. Навчальний матеріал має відповідати процесу застосування змісту предмета на практиці та сприяти виробленню не лише суто предметних умінь, а й умінь застосовувати знання в нетипових життєвих ситуаціях, працювати з проблемами, що пов'язані зі змістом інших предметних галузей, із реальними соціальними контекстами, узагальнювати й використовувати інформацію на основі своїх досліджень, оперувати різними джерелами інформації.

Зміст підручників має забезпечувати діяльнісний підхід до навчання. Необхідне постійне залучення учнів до різних видів навчальнопізнавальної діяльності; засвоєння оперативних знань, способів міркувань, прийомів діяльності; створення методичних ситуацій, які стимулюють самостійні відкриття учнями навчальних фактів; перенесення акцентів із збільшення обсягу навчальних текстів на вироблення вмінь їх використовувати для досягнення певних цілей.

Укрупнення навчального матеріалу підручника. Не віддаляти в навчальному часі вивчення аналогічних, схожих понять, взаємно обернених тверджень, операцій, - це сприятиме цілісності знань. Групування завдань за спільними способами розв'язання (ідеями, планами) та систематизація понять, властивостей, способів розв'язування задач (інфографіка, таблиці, графіки, діаграми, гістограми, схеми, класифікації) значно покращуватиме застосування знань до розвяязвання задач, зокрема практичного змісту.

Інтеграція змісту - ванлива вимога до сучасних щкільних підручників. Наразі потрібне суттєве посилення внутрішньопредметних і міжпредметних зв'язків, створення інтегрованих курсів через введення узагальнювальних понять відповідної науки.

Візуалізація навчальних текстів підручника, особливо з використанням комп'ютерних презентацій, програмних засобів навчального призна- 
чення. Супровід навчальних текстів новими інформаційними технологіями дає змогу викликати інтерес до навчання, активізувати навчальнопізнавальну, дослідницьку, проєктну діяльність учнів, посилити самостійність в опануванні компетентностями (сервіси для онлайн-навчання, для підтримки окремих його етапів або уроків, ППЗ для різних тем, типів задач).

Під час слухань склалося відчуття цілковитого взаєморозуміння та єднання в бажанні надати учням і вчителям якісну навчальну книжку. Залишається побачити реальні результати вирішення піднятих питань і прогресивних змін у сфері підручникотворення.

\section{СПИСОК ВИКОРИСТАНИХ ДЖЕРЕЛ}

Барановська, О. (2020). Сучасний підручник у руслі гуманітаризації навчального процесу: основні акценти. Проблеми сучасного підручника, (24), 513. https://doi.org/10.32405/2411-1309-2020-24-5-13

Бурда, М. (2020). Зміст підручників з математики у контексті результатів дослідження PISA-2018. Проблеми сучасного підручника, (24), 14-21. https://doi.org/10.32405/2411-1309-2020-24-14-21

Васильєва, Д.В., Головко, М.В., Жук, Ю.О., Козленко, О.Г., Ляшенко, О.І., Науменко, С.О., \& Новосьолова B.I. (2020). Уроки PISA-2018 : методичні рекомендації. Київ: Педагогічна думка. https://bit.ly/39ql8Gs

Верховна Рада України. (2021, 26 травня). Якість підручників та навчальних посібників для Нової української школи обговорено під час слухань у
Комітеті з питань освіти, науки та інновацій. https://www.rada.gov.ua/news/news_kom/209038.html Інститут педагогіки НАПН України. (n.d.). Електронна бібліотека. http://undip.org.ua/news/library/index.php

Кабінет Міністрів України. (2018, 21 лютого). Про затвердження Державного стандарту початкової освіmи (87). https://zakon.rada.gov.ua/laws/ show/87-2018-п

Комітет Верховної Ради України з питань освіти, науки та інновацій. (2021, 26 травня). Комітетські слухання: "Якість підручників та навчальних посібників для Нової української школи» [Відео]. Facebook. https://www.facebook.com/111988616871201/ videos/1854103584771074

Міністерство освіти і науки України. (2019, 8 жовтня). Про затвердження типових освітніх програм для 1-2 класів закладів загальної середньої освіти (1272). https://mon.gov.ua/ua/npa/pro-zatverdzhennyatipovih-osvitnih-program-dlya-1-2-klasiv-zakladivzagalnoyi-serednoyi-osviti

Міністерство освіти і науки України. (2019, 8 жовтня). Про затвердження типових освітніх програм для 3-4 класів закладів загальної середньої освіти (1273). https://mon.gov.ua/ua/npa/pro-zatverdzhennyatipovih-osvitnih-program-dlya-3-4-klasiv-zakladivzagalnoyi-serednoyi-osviti-1273

Міністерство освіти і науки України. (2020, 20 липня). Про затвердження Порядку надання грифів навчальній літературі та навчальним програмам (931). https://zakon.rada.gov.ua/laws/show/z1119-20

Топузов, О.М. (2015). Компетентнісні засади сучасного підручникотворення. Український педагогічний журнал, (3), 36-47. https://cutt.ly/5maobwb

DRAFT NEW PROCEDURE FOR COMPETITIVE SELECTION OF TEXTBOOKS

Report at the hearings in the Committee of the Verkhovna Rada of Ukraine on Education, Science and Innovations entitled "Quality of Textbooks and Training Manuals for the New Ukrainian School", May 26, 2021

\section{Oleh Topuzov}

DSc in Education, Professor, Full Member (Academician) of NAES of Ukraine, Vice-President, National Academy of Educational Sciences of Ukraine; Director, Institute of Pedagogy of the National Academy of Educational Sciences of Ukraine, Kyiv, Ukraine

Abstract. The report emphasizes the importance of Ukrainian educational book quality assurance, which confirms the educational process's success and is aimed at significant improvement of the school textbooks creation system and strengthening responsibility to society and the national school. The state of providing pupils and teachers in Ukraine with textbooks and training manuals is enlightened and its features are characterized. The scientific achievements of the Institute of Pedagogy of the National Academy of Educational Sciences of Ukraine researchers are presented; they've created more than 160 textbooks and manuals during 2018-2020. The requirements for a quality modern textbook are given, they are grounded on the results of a survey among pupils held by the Institute of Pedagogy of NAES of Ukraine researchers. Special attention is paid to the proposals of the National Academy of Educational Sciences of Ukraine researchers in order to ensure the proper quality of educational literature, in particular for the New Ukrainian School.

Keywords: educational book quality; textbooks expertise; textbooks creation; educational book publishing; Institute of Pedagogy of NAES of Ukraine. 